\title{
PELATIHAN KADER KESEHATAN REPRODUKSI REMAJA (KRR) DI SMA KABUPATEN INDRAGIRI HILIR
}

\author{
Nova Yulita ${ }^{1, *}$, Sellia Juwita ${ }^{2}$, Tina Mahrani ${ }^{3}$ \\ Program Studi Kebidanan, Fakultas Kedokteran dan Ilmu Kesehatan, Universitas Abdurrab \\ *Email: nova.yulita@univrab.ac.id
}

\begin{abstract}
ABSTRAK
Remaja dalam pandangan ilmu kedokteran dan ilmu-ilmu lain yang berkaitan masalah remaja, dikenal sebagai suatu tahap perkembangan fisik. Perkembangan fisik yaitu masa dimana alat-alat reproduksi remaja mencapai pematangannya, secara anatomis berarti alat-alat reproduksi remaja dari umur 15-20 tahun sudah berfungsi secara sempurna, hal ini juga diimbangi dengan keadaan tubuh pada umumnya memperoleh bentuknya yang dan sempurna secara fa'ali (alat-alat kelamin tersebut sudah berfungsi). Tujuan program ini adalah memberikan pengetahuan dan aplikasi ilmu secara langsung kepada remaja untuk dapat menjadi kader remaja untuk mengatasi masalah kesehatan reproduksi remaja khususnya pada wanita. Lokasi kegiatan ini akan dilaksanakan di SMA Negeri 1 Tembilahan Kota dan SMA Negeri 1 Tembilahan Hulu dan SMA Negeri Tuah Gemilang. Kegiatan pengabdian dilaksanakan dengan memberikan materi tentang pelatihan kader kesehatan reproduksi (KRR), dan memberikan langsung pelatihan kepada kader dari perwakilan sekolah dengan melakukan simulasi. Hasil kegiatan peserta sangat antusias saat melakukan bermain peran sebagai kader KRR dan dapat memahami perannya masingmasing dengan sangat baik. Peserta pelatihan sangat bangga menjadi kader dan menjadi perwakilan sekolah sebagai perpanjangan tangan kesehatan dalam program PK-KRR. Dari kegiatan pengabdian dapat dismpulkan bahwa setiap kader KRR yang terpilih menjadi perwakilan sekolah dapat memahami tugas dan tanggung jawabnya dan bersedia menjalankan tugas dengan baik.
\end{abstract}

Kata Kunci: Remaja, kader, kesehatan reproduksi remaja (KRR)

\section{ABSTRACT}

Adolescents in the view of medical science and other sciences related to adolescent problems, known as a stage of physical development. Physical development is the period in which the tools of reproduction of adolescents reach maturation, anatomically means reproductive tools of adolescents from the age of 1520 years has functioned perfectly, it is also balanced with the state of the body in general get a perfect shape and fa'ali (the genitals are already working). The purpose of this program is to provide knowledge and application of science directly to adolescents to be a cadre of teenagers to overcome the problem of adolescent reproductive health, especially in women. The location of this activity will be held in SMA Negeri 1 Tembilahan Kota and SMA Negeri 1 Tembilahan Hulu and SMA Negeri Tuah Gemilang. Devotional activities are conducted by providing materials on the training of reproductive health cadres (KRR), and providing direct training to cadres from school representatives by simulation. The results of the participants were very enthusiastic when performing role play as KRR cadres and able to understand their role very well. The trainees are very proud to be cadres and represent the school as an extension of health in PK-KRR program. From the dedication activities it can be concluded that every KRR cadres who are elected to represent the school can understand their duties and responsibilities and are willing to perform their duties

Keywords: Adolescent, cadres, adolescent reproductive health (KRR) 


\section{PENDAHULUAN}

Remaja dalam pandangan ilmu kedokteran dan ilmu-ilmu lain yang berkaitan masalah remaja, dikenal sebagai suatu tahap perkembangan fisik. Perkembangan fisik yaitu masa dimana alat-alat reproduksi remaja mencapai pematangannya, secara anatomis berarti alatalat reproduksi remaja dari umur 15-20 tahun sudah berfungsi secara sempurna, hal ini juga diimbangi dengan keadaan tubuh pada umumnya memperoleh bentuknya yang dan sempurna secara fa'ali (alat-alat kelamin tersebut sudah berfungsi)[1].

Pada era globalisasi dan modernisasi ini telah terjadi perubahan dan kemajuan disegala aspek dalam menghadapi perkembangan lingkungan, kesehatan dan kebersihan, dimana masyarakat dituntut untuk selalu menjaga kebersihan fisik dan organ atau alat tubuh. Salah satu organ tubuh yang penting serta sensitif dan memerlukan perawatan khusus adalah alat reproduksi. Pengetahuan dan perawatan yang baik merupakan faktor penentu dalam memelihara kesehatan reproduksi. Apabila alat reproduksi tidak dijaga kebersihannya maka akan menyebabkan infeksi, yang pada akhirnya dapat menimbulkan penyakit [2]

Perilaku higienis merupakan tema penting yang perlu ditelaah secara mendalam. Hal ini karena berdasarkan kajian teoritis yang ada, salah satu upaya mengurangi gangguan pada saat menstruasi yaitu membiasakan diri dengan perilaku higienis. Namun demikian perilaku higienis pada saat menstruasi tidak akan terjadi begitu saja, tetapi merupakan sebuah proses yang dipelajari karena individu mengerti dampak positif atau negatif suatu perilaku yang terkait dengan keadaan menstruasi [3].

Jika remaja putri melakukan perilaku higienis pada saat menstruasi maka akan terhindar dari kanker rahim, merasa nyaman beraktivitas sehari-hari, percaya diri, bersemangat dan tidak malas-malasan lagi, tidak dijauhi teman-teman karena bau badan amis dan tidak mempercayai mitos-mitos yang beredar di masyarakat karena sudah memahami kebenarannya

Edukasi tentang kesehatan reproduksi dan pendidikan seks pada remaja sangat penting, akan tetapi di Indonesia pendidikan seks masih dianggap sebagai sesuatu yang tabu oleh sebagaian masyarakat dalam budaya dan agama di Indonesia, sehingga sulit untuk mengimplementasikan tentang pendidikan kesehatan reproduksi secara formal melalui jalur kurikulum dalam institusi pendidikan sekolah [4]. Salah satu bentuk program atau akses dalam pemberian informasi mengenai kesehatan reproduksi dapat dilakukan melalui peer education.

\section{TINJAUAN PUSTAKA}

Kesehatan reproduksi ialah suatu kondisi sehat dari sistem, fungsi, dan proses alat reproduksi yang dimiliki oleh seseorang, yang tidak semata-mata bebas dari penyakit atau kecacatan, melainkan dalam semua hal yang berkaitan dengan sistem reproduksi, serta fungsi dan prosesnya. Tujuan dari program kesehatan reproduksi remaja adalah untuk membantu remaja agar memahami dan menyadari ilmu tersebut, sehingga memiliki sikap dan perilaku sehat dan tentu saja bertanggung jawab kaitannya dengan masalah kehidupan reproduksi [5].

Organ reproduksi merupakan alat dalam tubuh yang berfungsi untuk suatu proses kehidupan manusia dalam menghasilkan keturunan demi kelestarian hidupnya atau 
reproduksi. Agar dapat menghasilkan keturunan yang sehat dibutuhkan pula kesehatan dari organ reproduksi. Salah satu yang menjadi faktor utama terciptanya kesehatan yaitu selalu menjaga kebersihan diri atau personal hygiene [6]

Menjaga kesehatan vagina dimulai dari memperhatikan kebersihan diri. Indonesia merupakan daerah yang beriklim tropis, sehingga udara panas dan cenderung lembab sering membuat banyak berkeringat dibagian tubuh yang tertutup dan lipatan-lipatan kulit seperti didaerah alat kelamin. Kondisi ini menyebabkan mikroorganisme jahat terutama jamur mudah berkembang biak, yang akhirnya bisa menimbulkan infeksi (Profil kesehatan Indonesia, 2010).

\section{a. Ruang Lingkup Kesehatan Reproduksi}

1. Kesehatan ibu dan bayi baru lahir.

2. Pencegahan dan Penanggulangan Infeksi Saluran Reproduksi (ISR) termasuk PMSHIV/AIDS.

3. Pencegahan dan penanggulangan kompliasi aborsi.

4. Kesehatan reproduksi remaja.

5. Pencegahan dan penanganan infertilitas.

6. Kanker pada usia lanjut dan osteoporosis.

7. Berbagai aspek kesehatan reproduksi lain, misalnya kanker serviks, mutilasi genital, fistula, dll.

Menurut Anugoro [8], Konsep perawatan genetalia eksterna pada hari biasa dan selama menstruasi adalah sebagai berikut:

1. Cuci tangan sebelum menyentuh vagina. Tangan yang berada di luar secara bebas menjadi tempat yang baik untuk menempelnya berbagai kotoran dan bakteri.

2. Basuhlahvagina dari arah depan (vagina) menuju anus.

3. Gunakan sabun yang paling lembut setelah buang air kecil. Apabila alergi atau iritasi terhadap sabun yang paling lembut, gunakan air hangat.

4. Keringkan daerah vagina dan sekitarnya menggunakan handuk lembut atau tissue tanpa parfum, dan jangan pernah menggunakan handuk milik orang lain untuk mengeringkan vagina.

5. Ganti celana dalam 2-3 kali sehari, gunakan celana dalam yang bersih dan 100\% berbahan katun.

6. Cukurlah rambut vagina setidaknya 7 hari sekali dan maksimal 40 hari sekali untuk mengurangi kelembapan di dalam vagina.

7. Gunakan pembalut yang nyaman, berbahan lembut, menyerap seluruh darah yang keluar, melekat kuat pada celana dalam, tidak bocor, dan tidak menimbulkan alergi atau iritasi.

8. Saat perdarahan banyak, gantilah pembalut setidaknya 4-5 kali dalam sehari.

9. Cucilah tangan kembali setelah menyentuh vagina

\section{METODE PENELITIAN}

Kegiatan pengabdian masyarakat yang dilaksanakan di SMA di SMA Negeri 1 Tembilahan Kota, SMA Negeri 1 Tembilahan Hulu dan SMA Tuah Gemilang dengan motode pelatihan kader Kesehatan Reproduksi Remaja dengan tahapan kegiatannya adalah 
menyampaikan materi tentang Kesehatan reproduksi Remaja yaitu personal higiene selama menstruasi dan penanganan disminorea, membentuk kader remaja untuk menerapkan program Peduli Kesehatan Reproduksi Remaja.

\section{HASIL}

Kegiatan pengabdian ini dilakukan pada tanggal 6-8 Maret 2017 di SMA Tembilahan mulai pukul 07:00 WIB sampai dengan selesai. Pengabdian dilakukan di Aula sekolah SMA 1 Tembilhan Kota, SMA 1 Tembilahan Hulu dan SMA Tuah Gemilang dengan keterangan sebagai berikut:

Tabel. 3.1 Peserta Pelatihan Kader

\begin{tabular}{|c|c|c|}
\hline No & Nama sekolah & Jumlah \\
\hline 1 & SMA N 1 Tembilahan Kota & 34 \\
\hline 2 & SMA N 1 Tembilahan Hulu & 29 \\
\hline 3 & SMA Negeri Tuah Gemilang & 25 \\
\hline
\end{tabular}

Kegiatan pengabdian masyarakat dilakukan selama tiga hari di SMA yang berada di Kabupaten Indragiri Hilir tepatnya di SMA N 1 Tembilahan Kota, SMA N 1 Tembilahan Hulu dan SMA Negeri Tuah Gemilang. Kegiatan pengabdian berupa pelatihan Kader KRR ini diterima dengan sangat baik oleh pihak sekolah dan kalangan siswa. Selama dalam rangkaian kegiatan pihak sekolah sangat membantu dalam hal teknis dan kelengkapan yang diperlukan. Selama penyampaian materi dan simulasi siswa sangat antusias dalam mengikutikegiatan ini hal ini ditandai dengan respon siswa yang saling memberikan tanggapan dan sumbang saran.

Materi Pelatihan diberikan oleh Nova Yulita, SST., M.Keb, Sellia Juwita, SST., M.Kes, dan Tina Mahrani, STr.Keb. Pelatihan Kader KRR di SMA N 1 Tembilahan Kota dari 34 peserta dibagi menjadi 6 kelompok kecil, SMA N 1 Tembilahan Hulu peserta berjumlah 29 orang dan dibagi menjadi 5 kelompok kecil dan SMA Negeri Tuah Gemilang dari 25 peserta dibagi menjadi 4 kelompok kecil untuk melakukan simulasi sebagai Kader KRR di lingkunagan sekolah.

Selama penyampaian materi peserta pelatihan sangat antusias dalam memperhatiakan dan saling memberi masukan tentang hal yang telah mereka ketahui melalui media informasi seperti televisi, tenaga kesehatan, media massa. Diskusi sangat bermanfaat bagi semua pserta dimana dapat menambah pengetahuan yang dapat diterapkan dalam kehidupan seharihari. Misalnya dalam hal merawat kebersihan organ reproduksi wanita selama menstruasi.

Menurut [8], Konsep perawatan genetalia eksterna pada hari biasa dan selama menstruasi adalah sebagai berikut: cuci tangan sebelum dan setelah menyentuh vagina, basuhlah vagina dari arah depan (vagina) menuju anus, keringkan daerah vagina dan sekitarnya menggunakan handuk lembut atau tissue tanpa parfum, ganti celana dalam 2-3 kali sehari, gunakan celana dalam yang bersih dan $100 \%$ berbahan katun, cukurlah rambut vagina setidaknya 7 hari sekali dan maksimal 40 hari sekali untuk mengurangi kelembapan di dalam vagina, gunakan pembalut yang nyaman tidak menimbulkan alergi atau iritasi.

Setelah penyampaian materi dilanjutkan dengan simulasi atau bermain peran sebagai kader KRR. Simulasi berjalan dengan baik lebih kurang selama tiga jam di setiap sekolah. Dari hasil simulasi dapat dilihat bahwa seluruh peserta dapat memainkan perannya dengan sangat baik. Peserta dapat memahami peran sebagai Kader KRR sesuai dengan tugas 
pokoknya. Setelah mengikuti pelatihan setiap kader KRR diberikan pin pengenal sebagai Kader di sekolah masing-masing.

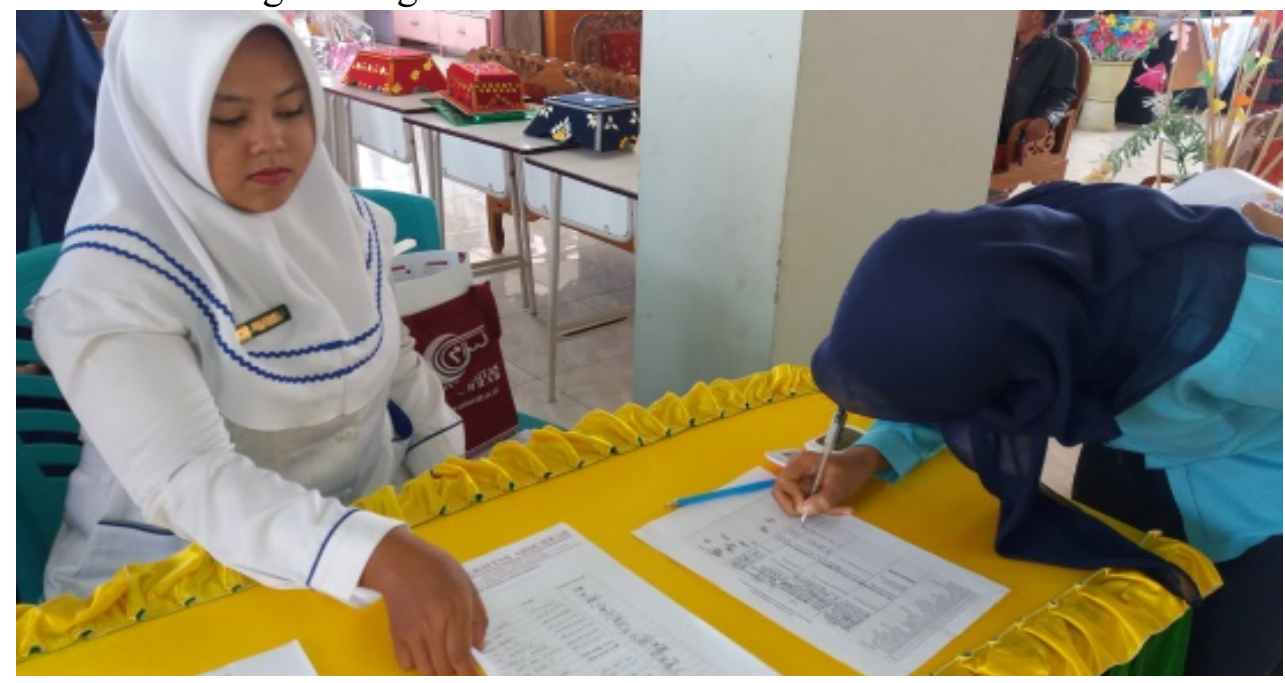

Registrasi peserta

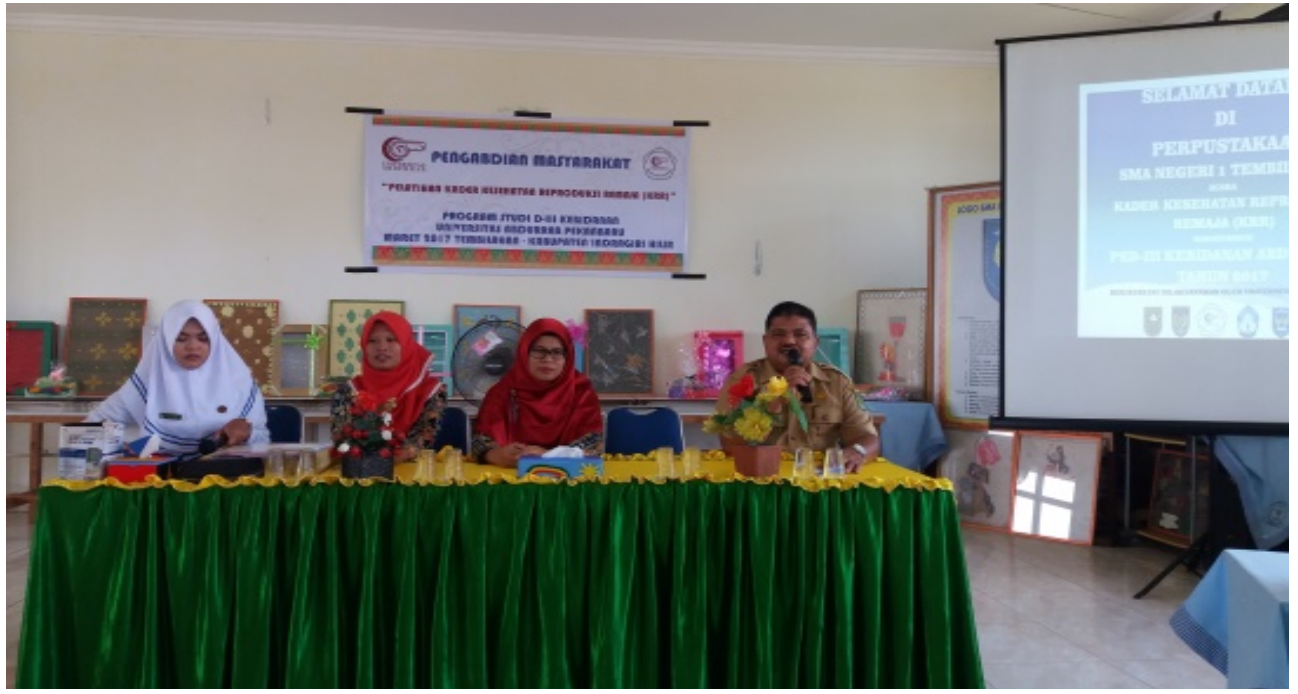

Sambutan Kepala Sekolah 


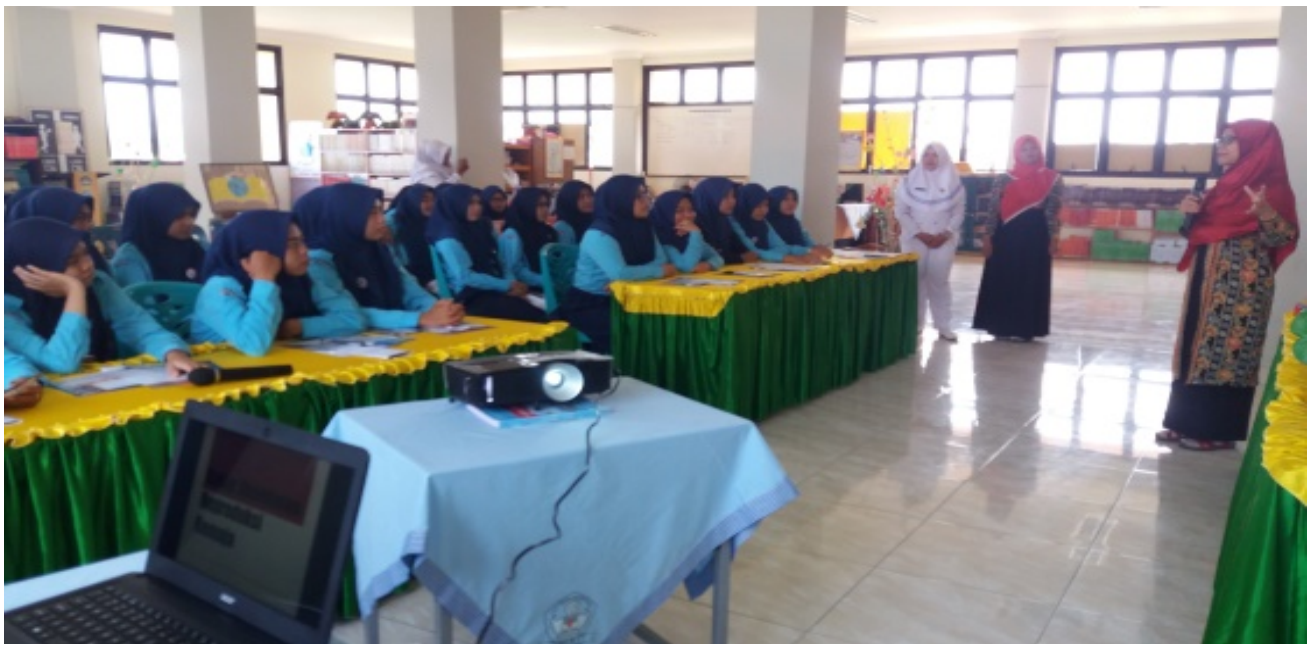

\section{Penyampaian Materi}
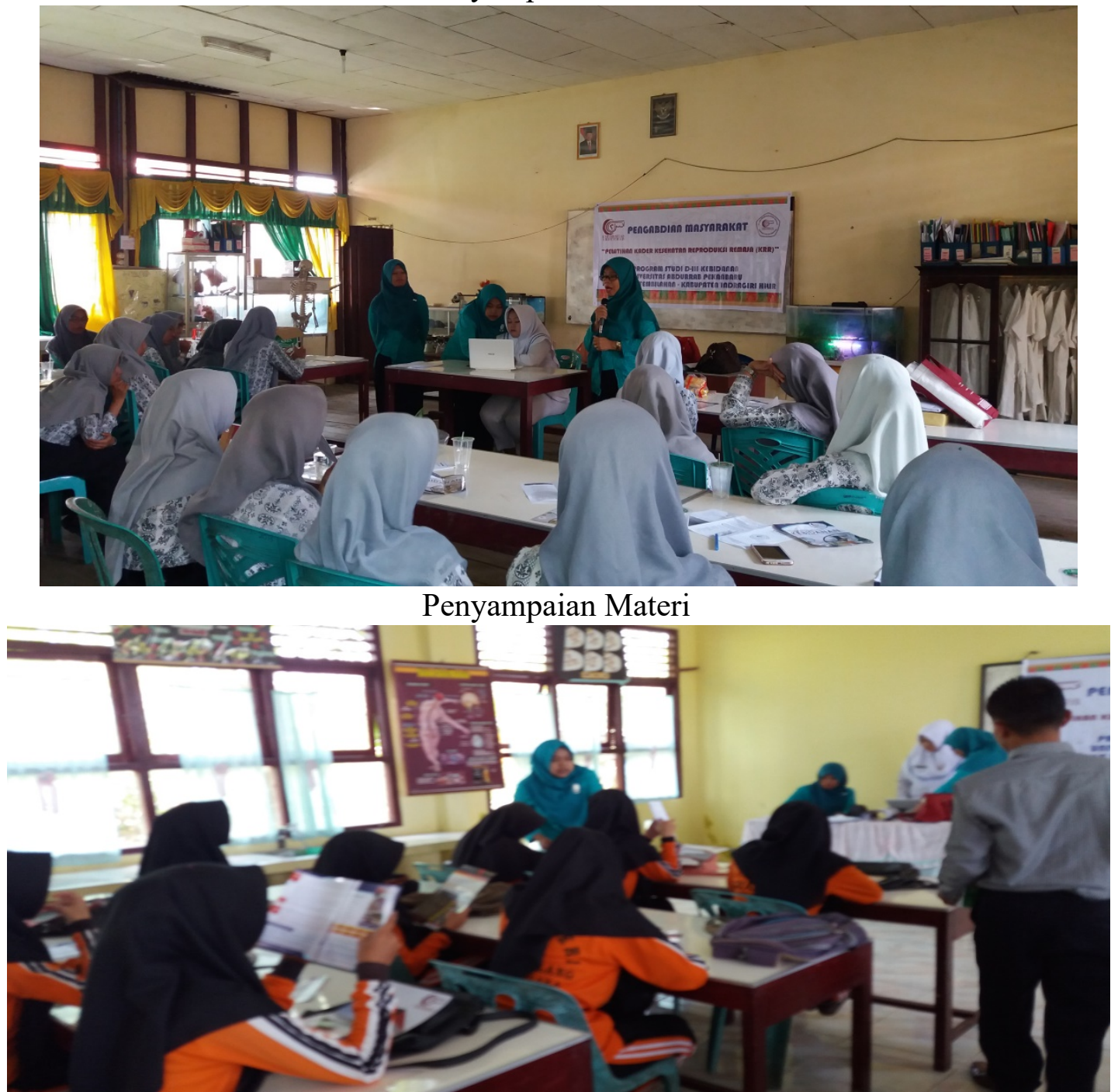

Penyampaian Materi 

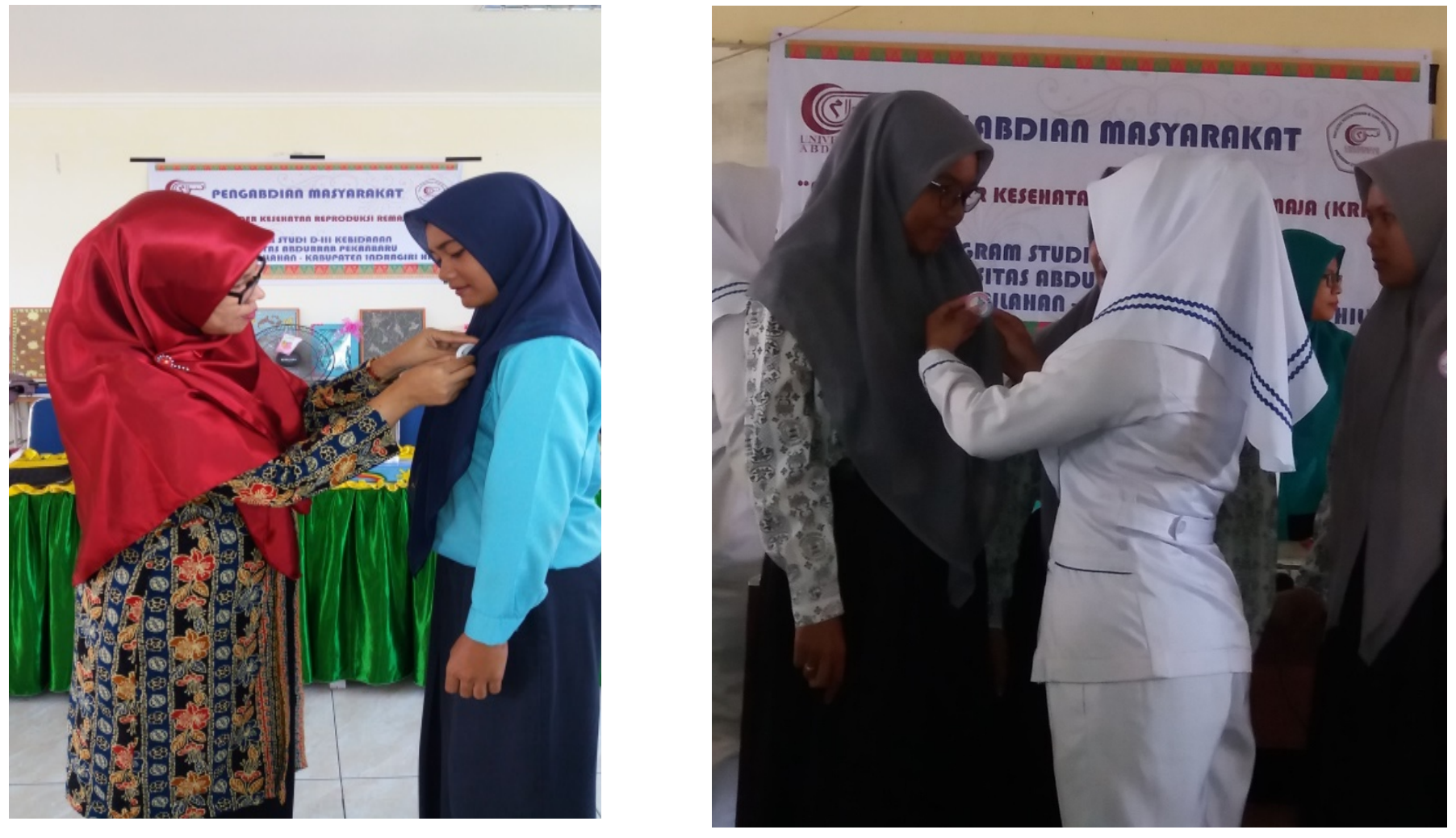

Pemasangan PIN Kader KRR

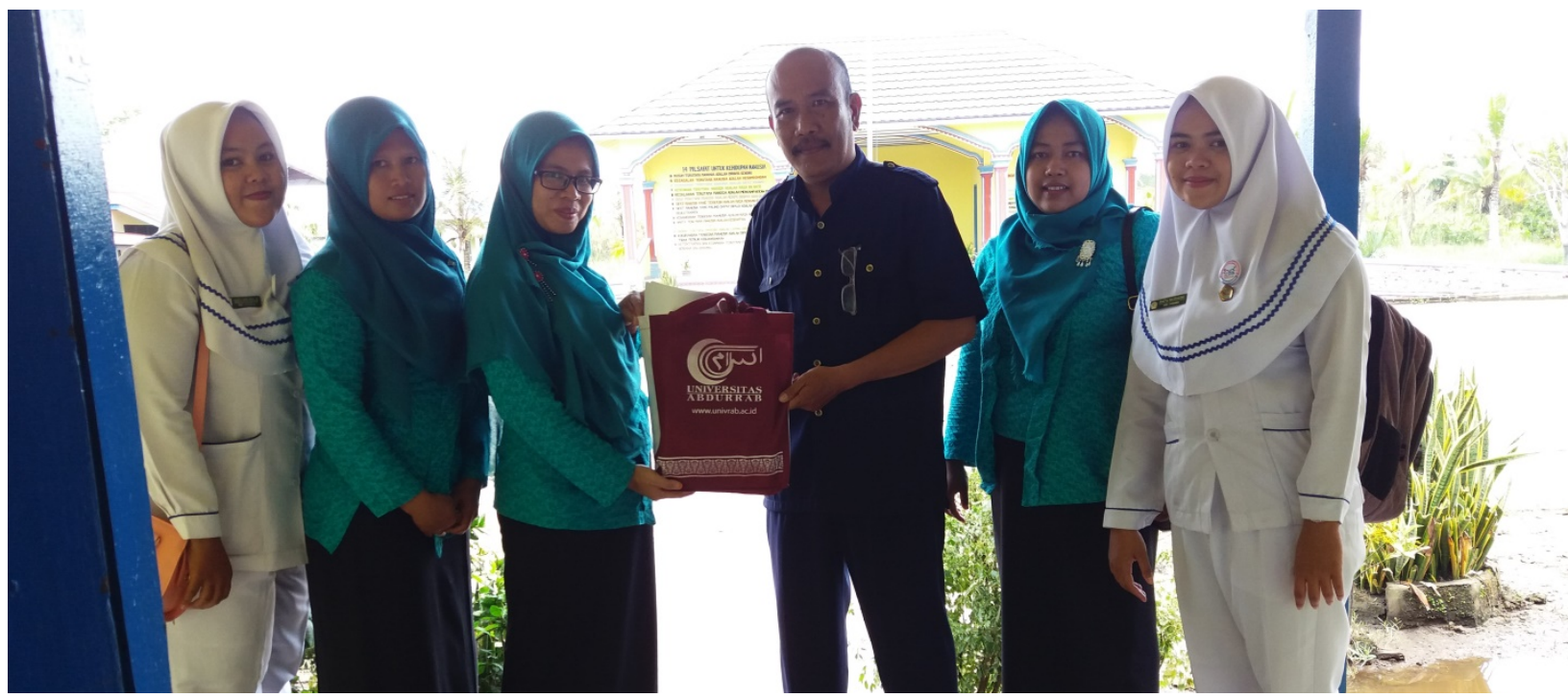

Penyerahan kenang-kenangan 


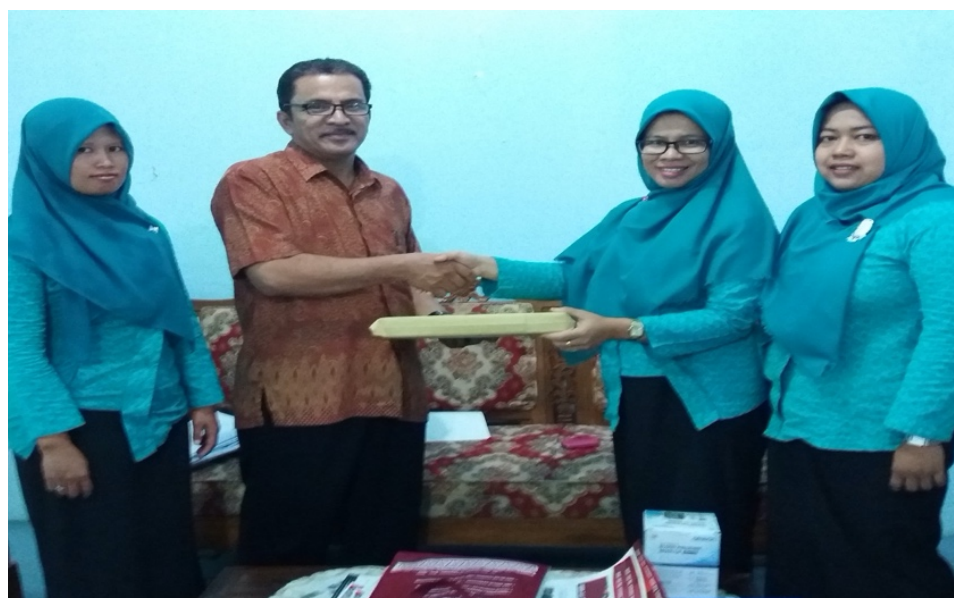

Penyerahan kenang-kenangan

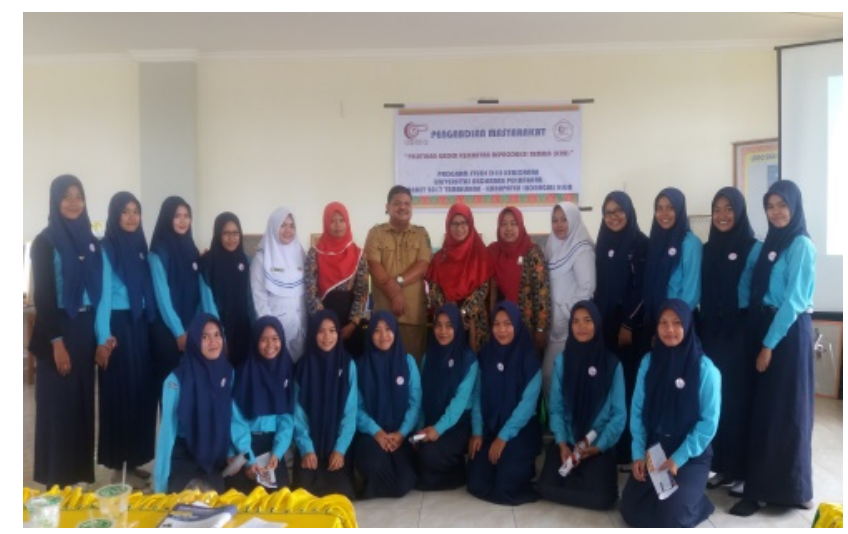

Foto bersama

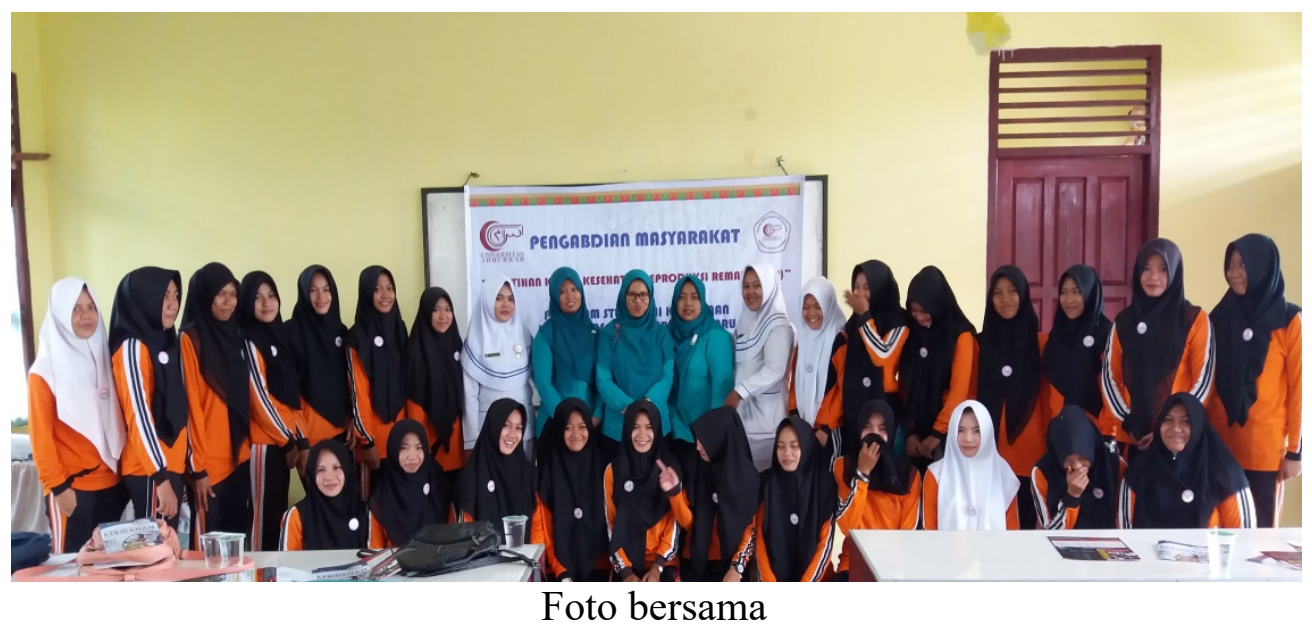




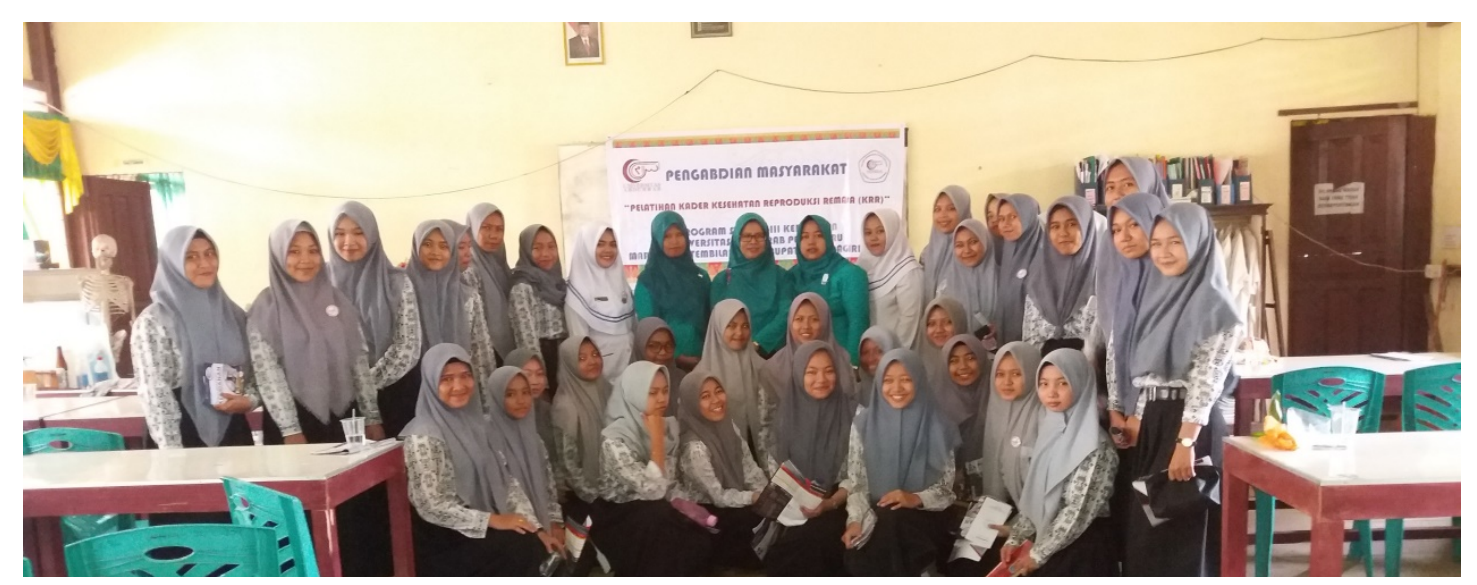

Foto bersama

\section{KESIMPULAN}

Kegiatan pengabdian berupa pelatihan Kader KRR ini terlaksan dengan lancer dan diterima dengan sangat baik oleh pihak sekolah dan kalangan siswa. Kegiatan ini sangat bermanfaat dan meningkatkan pengetahuan siswa tentang kesehatan reproduksi remaja. Siswa yang telah dilantik menjadi kader KRR lebih memahami tugas dan perannya sebagai kader KRR di sekolah.

\section{DAFTAR PUSTAKA}

S. W. Sarwono, Psikologi Remaja. Jakarta: PT Raja Grafindo Persada, 2013.

Harahap, kesehatan Reproduksi. Bagian Kedokteran komunitas dan kedokteran pencegahan.

Fakultas kedokteran Universitas Sumatra Utara, 2007.

D. P. Indriastuti, Hubungan Antara Pengetahuan Kesehatan Reproduksi dengan Perilaku Higienis Remaja Putri Pada Saat Menstruasi. 2009.

A. Imron, Pendidikan Kesehatan Reproduksi Remaja. Jogjakarta: ArRuzz Media, 2012.

Y. dkk Widyastuti, Kesehatan Reproduksi. Yogyakarta: Fitra maya, 2009.

E. B. Hurlock, Psikologi Perkembangan: Suatu Pendekatan Sepanjang Rentang Kehidupan. Jakarta: Erlangga, 2010.

D. K. RI, "Profil kesehatan Indonesia 2009," 2010.

A. Anurogo, Dito Dan Wulandari, Cara Jitu Mengatasi Haid. Yogyakarta: Andi, 2011. 